\section{Check for updates}

Cite this: J. Mater. Chem. A, 2018, 6 , 14787

\title{
Sulfur: an intermediate template for advanced silicon anode architectures $\dagger$
}

\author{
Anne Baasner, (D) ab Susanne Dörfler, (D) ${ }^{* b}$ Markus Piwko, ${ }^{\text {ab }}$ Sébastien Desilani, ${ }^{c}$ \\ Jan Brückner, ${ }^{\mathrm{b}}$ Holger Althues ${ }^{\mathrm{b}}$ and Stefan Kaskel (DD ab
}

The lithium-sulfur chemistry provides a next generation battery technology on the verge of commercialization with significantly increased specific energy. However, the cycle life mainly suffers from dendrite and continuous SEI formation in lithium anodes inducing active material and electrolyte depletion. Here, we report on a silicon-carbon composite anode as a stable alternative anode for safe $\mathrm{Li}-\mathrm{S}$ cells. Well-defined sulfur coatings generate a shell for a silicon core (Si@S) to further form a carbon shell (Siasasucrose). After sulfur removal the void structure (Siavoid@C) allows to compensate the mechanical stress imposed by the huge volume change during the lithiation of the silicon. In this case, sulfur is not only used as a low cost and high capacity cathode material but also as a template to create free volume. It is easily removed during the pyrolysis and no acid leaching steps are required. In half cell tests vs. lithium a high capacity of $2270 \mathrm{~mA} \mathrm{~h} \mathrm{gsi}{ }^{-1}\left(690 \mathrm{~mA} \mathrm{~h} \mathrm{~g}^{-1}\right)$ was achieved in the $10^{\text {th }}$ cycle and the reversible lithiation of the silicon particles could be ensured for more than 50 cycles. The prelithiated $\mathrm{Si}-\mathrm{C}$ anode with a high areal capacity of $2 \mathrm{~mA} \mathrm{~h} \mathrm{~cm}^{-2}$ was successfully matched with a sulfur cathode in a SLS full cell on coin cell and on pouch cell levels. A high capacity of about $807 \mathrm{~mA} \mathrm{~h} \mathrm{gsulfur}^{-1}\left(2^{\text {nd }}\right.$ cycle) was reached with a low lithium excess of only $76 \%$ compared to $2000 \%$ lithium excess in stateof-the-art Li-S cells.

Received 20th April 2018

Accepted 1st July 2018

DOI: $10.1039 / \mathrm{c} 8 \mathrm{ta0} 3647 \mathrm{k}$

rsc.li/materials-a elements regarding a full lithiation to $\mathrm{Li}_{15} \mathrm{Si}_{4}$ and the delithiation occurs at a low voltage around $0.4 \mathrm{~V} v s$. $\mathrm{Li}^{\mathrm{L}} \mathrm{Li}^{+} .7$ During the lithiation process of silicon a large undesirable volume expansion (about $300 \%$ ) takes place. ${ }^{8}$ This volume expansion and contraction can lead to the pulverization of the electrode and the loss of electrical contact between silicon and the current collector. This results in a low coulombic efficiency (CE) and rapid capacity fading during the galvanostatic cycling. Another crucial failure mechanism is the unstable SEI at the silicon surface which is cracked by mechanical stress and formed repeatedly consuming the electrolyte comparable to lithium metal anodes. ${ }^{9}$

Recently, significant progress has been made by using nanoscale silicon structures like nanoparticles, ${ }^{\mathbf{1 0}-16}$ thin films, ${ }^{8,17-19}$ nanotubes, ${ }^{20-22}$ nanowires ${ }^{23-27}$ and nanoporous silicon $^{28-32}$ to overcome these problems. ${ }^{33}$ Several of these $\mathrm{Si}$ based anodes were coupled with a sulfur cathode to generate a SLS full cell reducing the lithium excess..$^{3-6,8,15,17,25-27,31,32,34}$ To improve the electrical contact a carbon matrix is introduced in many cases..$^{35-37} \mathrm{~A}$ higher stability of the anode in the resulting SLS cell was shown. ${ }^{14,16,34,38-41}$ Nanostructured silicon-carbon composites with free volume between the silicon core and the carbon shell can potentially compensate the volume change and ensure the formation of a stable SEI at the surface of the carbon shell preventing electrolyte consumption during cycling. ${ }^{42-44}$ In many publications, free volume is generated by etching silicon

\footnotetext{
${ }^{a}$ Department of Inorganic Chemistry, Dresden University of Technology, Bergstraße 66, 01062 Dresden, Germany

${ }^{b}$ Fraunhofer Institute for Material and Beam Technology (IWS), Winterbergstraße 28, 01277 Dresden, Germany. E-mail: susanne.doerfler@iws.fraunhofer.de ${ }^{\prime} O x i s$ Energy, E1 Culham Science Centre, OX14 3DB Abingdon, UK

$\dagger$ Electronic supplementary information (ESI) available. See DOI: $10.1039 / \mathrm{c} 8 \mathrm{ta} 03647 \mathrm{k}$
} 
or a sacrificial silica template with toxic and hazardous hydrofluoric acid. ${ }^{43,45-55}$

Some other groups used sodium hydroxide or lithium hydroxide instead of hydrofluoric acid for partially etching the silicon. ${ }^{49,56}$ However, these treatments comprise washing steps and hence, result in the loss of silicon. Especially wet-chemical washing/drying steps are hardly scalable and therefore, less applicable in industrial production.

In contrast, an elegant template is elemental sulfur by itself. ${ }^{57}$ Melt coating on commercially available silicon nanoparticles (SiNPs) provides a high degree of control. Via a wet chemical process, sucrose as a low-cost, non-toxic, environmentally friendly carbon source is polymerized around the sulfur coated silicon particles. During the carbonization of the polymerized sucrose, sulfur is removed in situ and a void between the silicon core and carbon shell is obtained. No further washing steps are needed rendering this synthesis scheme rather promising for production. It makes use of industrial sulfur waste and reformulates it into a highly tailored nanostructured void architecture. Commercially available silicon powder with mostly aggregated particles and a broad particle size distribution could be used as a widely available und a relatively inexpensive source of nanostructured silicon.

Through galvanostatic cycling vs. lithium (half cells) an increased electrochemical stability of the nanostructured silicon-carbon ( $\mathrm{Si}-\mathrm{C})$ composite has been demonstrated when compared to $\mathrm{Si}-\mathrm{C}$ composites without free volume and the asreceived SiNPs resulting in an increased cycle stability and lithiation capacity. Finally, the cycle life of Li-S cells is prolonged without loss of capacity by the substitution of the lithium metal with a prelithiated $\mathrm{Si}-\mathrm{C}$ anode. The feasibility of this cell concept could be shown both on coin and on pouch cell levels.

\section{Results and discussion}

\subsection{Structural characterization}

To overcome the electrode degradation caused by the volume change of the silicon during lithiation a nanostructured $\mathrm{Si}-\mathrm{C}$ composite (Si@void@C) with tailored voids is synthesized as illustrated in Fig. 1.

Transmission electron microscopy (TEM) evidences the void structure formation (Fig. 2). A uniform sulfur coating (5-20 nm thick) of the SiNPs (50-150 nm diameter) (Fig. 2a) protecting the



Fig. 1 Schematic illustration of the synthesis process of the nanostructured silicon-carbon composite (SiavoidaC).

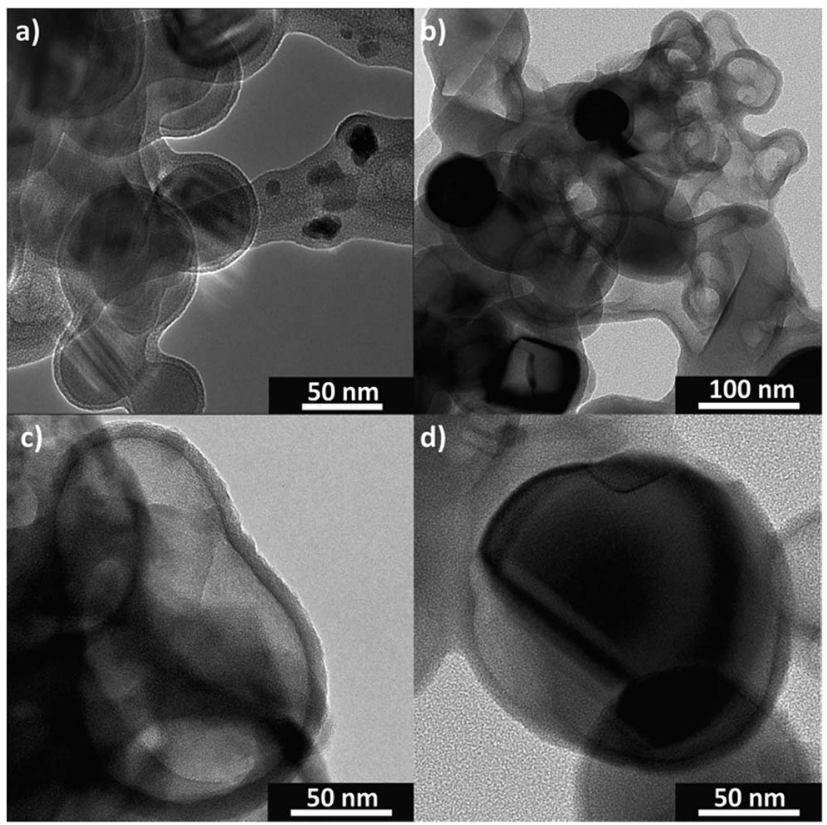

Fig. 2 TEM images of the sulfur coated SiNPs (Si@S) (a) and the resulting silicon-carbon void structure (Si@void@C) $(b-d)$.

SiNPs from decomposition during the alkaline treatment of the sucrose polymerization is obtained. Without the sulfur layer, the SiNPs are not stable during the synthesis in alkaline medium (Fig. S1 $\dagger$ ).

The resulting void structure contains voids with a diameter about $50-150 \mathrm{~nm}$ with a nearly $10 \mathrm{~nm}$ thick carbon shell (Fig. 2b-d). Obviously, the free volume does not completely compensate the lithiated silicon volume expansion of $300 \%$. But introducing larger voids by a thicker sulfur shell led to poor electrical contact of the silicon cores (Fig. S2†). This phenomenon was also shown by other groups ${ }^{45,46}$ However, due to the tailored voids the carbon matrix gains enough flexibility to compensate the volume change of the silicon.

The TEM images in Fig. 2 as well as the SEM images in Fig. 3 show that commercially available SiNPs (Fig. 3a and b) are



Fig. 3 SEM images of the as-received SiNPs ( $a$ and $b$ ) and of the Si-C composite (Si@void@C) (c and d). 
partially aggregated - a typical phenomenon observed for nanoparticles in order to minimize the surface energy.

This affects the morphology of the Si-C composite (Fig. 3c and d): mostly, particle aggregates are coated instead of individual particles. Nevertheless, with the resulting carbon coating, the silicon particles seem to be covered completely. The coated primary silicon particles are approximately 100-200 nm in diameter and form micrometer-sized agglomerates that decrease the surface area and the tap density of the composite. ${ }^{58}$ X-ray powder diffraction (PXRD) and Raman spectroscopy results as shown in Fig. 4 confirm the stability and intactness of crystalline SiNPs throughout the synthesis process. PXRD of the SiNPs and the Si-C composite (Fig. 4a) shows the typical diffraction pattern of cubic silicon. ${ }^{48}$ No diffraction peaks corresponding to graphitic carbon or silica could be observed in the PXRD pattern.

However, the emergence of amorphous silica phases during the alkaline treatment cannot be excluded. For this reason, Raman studies were carried out as well to reveal the absence of a characteristic band of the amorphous silica around $460 \mathrm{~cm}^{-1}{ }^{59}$ The Raman spectrum of the $\mathrm{Si}-\mathrm{C}$ composite shown in Fig. $4 \mathrm{~b}$ exhibits a strong peak at $520 \mathrm{~cm}^{-1}$ corresponding to the characteristic peak of pure SiNPs. Another characteristic but weaker peak at $974 \mathrm{~cm}^{-1}$ of silicon is not visible. ${ }^{60}$ The two


Fig. 4 PXRD pattern (a) and Raman spectra (b) of bare SiNPs and the $\mathrm{Si}-\mathrm{C}$ composite confirm the stability of the crystalline silicon nanoparticles during the synthesis. broad peaks of the Si-C composite at about $1350 \mathrm{~cm}^{-1}$ and $1600 \mathrm{~cm}^{-1}$ could be explained by the disordered $\mathrm{D}$ band and the graphitic $\mathrm{G}$ band of the carbon matrix. By fitting the spectra with a Lorentzian function to calculate the intensities of the $\mathrm{D}$ band and the $\mathrm{G}$ band, the degree of graphitization $I_{\mathrm{D}} / I_{\mathrm{G}} \sim 1$ is calculated. ${ }^{61}$ That means that the carbon shell of the $\mathrm{Si}-\mathrm{C}$ composite has a short-range-ordered carbon structure that matches well with the TEM investigations where clear carbon fringes are hardly observable. The silicon content of the Si-C composite which is around $30 \%$ was determined via an adapted stepwise combustion of the carbon matrix and oxidation of the silicon under air at $1000{ }^{\circ} \mathrm{C}$ (Fig. S3†).

The removal of the sulfur template during the pyrolysis is investigated and monitored by thermal gravimetric mass spectrometry (TGA-MS) displayed in Fig. 5. Firstly, the composite is heated under argon flow at $10 \mathrm{~K} \mathrm{~min}^{-1}$ to $850{ }^{\circ} \mathrm{C}$ and annealed for $2 \mathrm{~h}$. The highest mass loss is at around $300{ }^{\circ} \mathrm{C}$ which is related to the carbonization of the polymerized sucrose and the removal of sulfur (Fig. 5a). According to the mass spectra of the evolved gas species (Fig. 5b), sulfur is decomposed presumably to hydrogen sulfide ( $\left.\mathrm{HS}, \mathrm{H}_{2} \mathrm{~S}\right)$, sulfur monoxide $\left(\mathrm{SO}, \mathrm{SO}_{2}\right)$ and disulphur $\left(S_{2}\right)$ matching the respective molar masses. The sulfur template could be removed almost completely and just around $8 \%$ sulfur remains in the $\mathrm{Si}-\mathrm{C}$ composite, which was determined by CHNS elemental analysis.

\subsection{Electrochemical characterization}

2.2.1 Half cell testing. For general electrochemical characterization, the $\mathrm{Si}-\mathrm{C}$ electrodes are galvanostatically cycled in half cells $v s$. an elemental $\mathrm{Li}$ anode. The silicon-carbon void structure electrode (Si@void@C) is compared with a siliconcarbon composite electrode without a void structure (Si@C) and an electrode containing bare silicon nanoparticles (SiNPs). Fig. 6 shows the resulting lithiation capacity and the CE. The lithiation is both calculated based on the total mass of the electrode (Fig. 6a) and on the silicon fraction in the electrode (Fig. 6b), whereby the capacity from the lithium intercalation in the carbon matrix $\left(220 \mathrm{~mA} \mathrm{~h} \mathrm{~g}^{-1}\right)$ is subtracted in the case of the Si@C and the Si@void@C electrode. A value of $220 \mathrm{~mA} \mathrm{~h} \mathrm{~g}{ }^{-1}$ was obtained by analyzing an analogue pyrolyzed carbon precursor without SiNPs (Fig. S4 $\dagger$ ).

In the first cycle, the electrode with pure SiNPs shows the highest capacity of $3094 \mathrm{~mA} \mathrm{~h} \mathrm{~g}^{-1}$ based on the electrode mass because of the highest silicon content of $80 \%$ (Fig. 6a). The Si@C electrode contains 42\% silicon and the Si@void@C electrode contains $23 \%$ silicon resulting in initial capacities of $1570 \mathrm{~mA} \mathrm{~h} \mathrm{~g}^{-1}$ and $1335 \mathrm{~mA} \mathrm{~h} \mathrm{~g}^{-1}$. During the first cycle all three silicon electrodes show a high irreversible capacity corresponding to an initial coulombic efficiency lower than $100 \%$. On one side, there is a loss of electrically contacted active material because silicon is strained by the large mechanical stress during the initial lithiation of the crystalline SiNPs. On the other hand, the electrolyte is reductively decomposed at the anode surface where the solid decomposition products form a SEI which ideally inhibits further electrolyte reduction. The Si@void@C electrode has the lowest CE of $47 \%$ followed by the 
a)

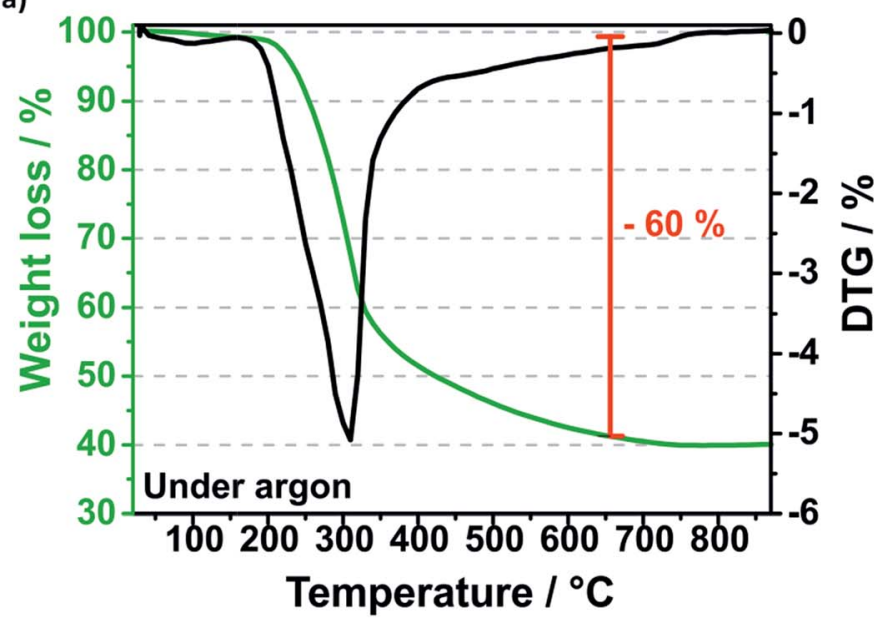

b)

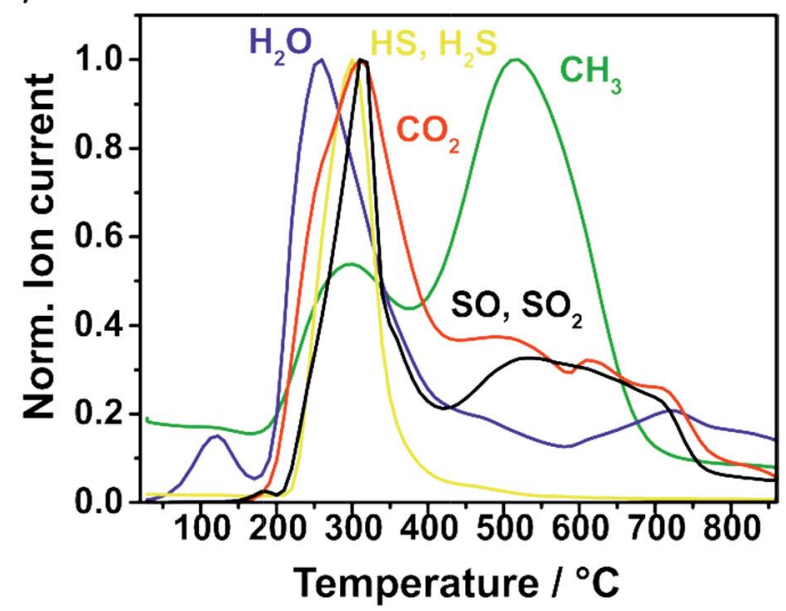

Fig. 5 TGA profile of the pyrolysis (under argon) of the Si@S@ sucrose compound (a) and the evolved gases detected by mass spectrometry (b).

Si@C electrode with $64 \%$ and the SiNP electrode with $72 \%$. Since sucrose is used as carbon source, the $\mathrm{Si}-\mathrm{C}$ composites consist of a porous unordered carbon coating with dangling bonds. This leads to an increased surface of the composite which reacts with the electrolyte. Besides the SEI formation on the carbon surface, there is also a partially irreversible lithium intercalation in the carbon matrix leading to the higher initial loss of lithium. According to Chen et al. the $\mathrm{CE}$ of the Si@void@C electrode is lower than that of the Si@C electrode given that the surface area is increased by the higher void volume..$^{53}$ In accordance to other publications, the CE of the $\mathrm{Si}-\mathrm{C}$ anodes is much better in carbonate based electrolyte like LP30 (1 $\mathrm{M} \mathrm{LiPF}_{6}$ in 1:1 (m/m) ethylene carbonate/dimethyl carbonate) which is standardly used in lithium-ion batteries (Fig. S5 $\dagger$ ). ${ }^{14}$ But these groups of electrolytes could to be used in the lithium-sulfur chemistry because polysulfides react with carbonates. ${ }^{62}$ In this way a commonly used lithium-sulfur battery electrolyte containing $1 \mathrm{M}$ bis(trifluoromethane)sulfonamide lithium salt (LiTFSI) and $0.25 \mathrm{M} \mathrm{LiNO}_{3}$ in $1: 1$ (v/v) 1,2-dimethoxyethane (DME) and 1,3-dioxolane (DOL) is used. Lithium nitrate is beneficial for $\mathrm{Li}-\mathrm{S}$ cells as it forms $\mathrm{Li}_{x} \mathrm{SO}_{y}$-based SEIs on the anode side suppressing the polysulfide shuttle. ${ }^{63}$

Certainly, the low initial CE is a characteristic signature of many silicon anodes which has to be solved regarding the use of silicon anodes in lithium-ion batteries where the loss of lithium ions is crucial. ${ }^{62}$ In the case of $\mathrm{Li}-\mathrm{S}$ batteries it is less critical because a prelithiated silicon anode with an already formed SEI is used. As expected, the SiNP electrode suffers from fast degradation as a result of the large volume change of the silicon whereby the SiNPs lose their electrical contact (Fig. 6a). Within 15 cycles the capacity declines to $387 \mathrm{~mA} \mathrm{~h} \mathrm{~g}^{-1}$ and the silicon can no longer be lithiated. After 9 cycles the CE rises to over $100 \%$ which could be related to the end of the reversible lithiation/delithiation. In the same way, the Si@C electrode shows a rapid capacity fading and a CE around $90 \%$ right from the start. Similar to the SiNP electrode the silicon cannot be reversibly lithiated after 15 cycles and the CE increases above 100\%. The Si@void@C electrode achieves a relatively high lithiation capacity of $692 \mathrm{~mA} \mathrm{~h} \mathrm{~g}^{-1}$ after 10 cycles and high capacity retention for more than 50 cycles. Since the carbon shell is not cracked by the volume change, the SEI is stabilized at the carbon surface, and the CE is increased to around $98 \%$ in a few cycles and remained at this value there for more than 40 cycles. It also enables a good rate capability (Fig. S6a $\dagger$ ).

In Fig. $6 \mathrm{~b}$ the capacity calculated based on the silicon fraction is compared to the theoretical capacity of $\mathrm{Li}_{15} \mathrm{Si}_{4}$ (3579 $\left.\mathrm{mA} \mathrm{h} \mathrm{g}_{\mathrm{Si}}{ }^{-1}\right)$. Due to the SEI formation and other lithium consuming side reactions, the capacity calculated based on the silicon mass of the SiNPs and the Si@void@C electrode is higher than the theoretical capacity of $\mathrm{Li}_{15} \mathrm{Si}_{4}$ in the first cycle. ${ }^{63}$ The Si@void@C electrode shows a capacity of $2255 \mathrm{~mA} \mathrm{~h} \mathrm{~g}{ }_{\mathrm{Si}}{ }^{-1}$ in the second cycle which corresponds to a utilization of silicon of 63\%. After 15 cycles still 61\% of the silicon in the Si@void@C could be lithiated, whereas the silicon in the SiNP electrode and the Si@C electrode could not be used.

As can be seen from the voltage profiles the first lithiation of the silicon consists of two parts (Fig. 6c-e): the potential decreases slowly to $0.1 \mathrm{~V}$ corresponding to the SEI formation and the Li intercalation in the carbon matrix. At a potential of ca. $0.1 \mathrm{~V}$ there is a plateau related to the lithiation of crystalline silicon to amorphous $\mathrm{Li}_{15} \mathrm{Si}_{4} \cdot{ }^{64}$ The delithiation of the unstable $\mathrm{Li}_{15} \mathrm{Si}_{4}$ correlates with the charge plateau around $0.45 \mathrm{~V}{ }^{65}$ After the first cycle the silicon becomes amorphous and thus, there is no flat plateau during the discharge process in the following cycles. ${ }^{64}$ Due to the degradation of the SiNPs and the Si@C electrode, the charge plateau around $0.45 \mathrm{~V}$ is not visible in the 10 th and in the 50th cycle and finally a charge cut-off voltage of $1 \mathrm{~V}$ could not be reached.

Regarding the potential use of the Si@void@C in commercial lithium-sulfur or lithium-ion cells the areal capacity is one crucial parameter. ${ }^{25}$ Many publications show Si-C electrodes with high cycle stability but low electrode loading causing a poor area related capacity. ${ }^{\mathbf{5 0 , 5 8 , 6 6}}$ Fig. 6 f reveals the dependency of the electrode loading and the electrode stability. Typically, with an increasing electrode thickness the influence of the 
a)

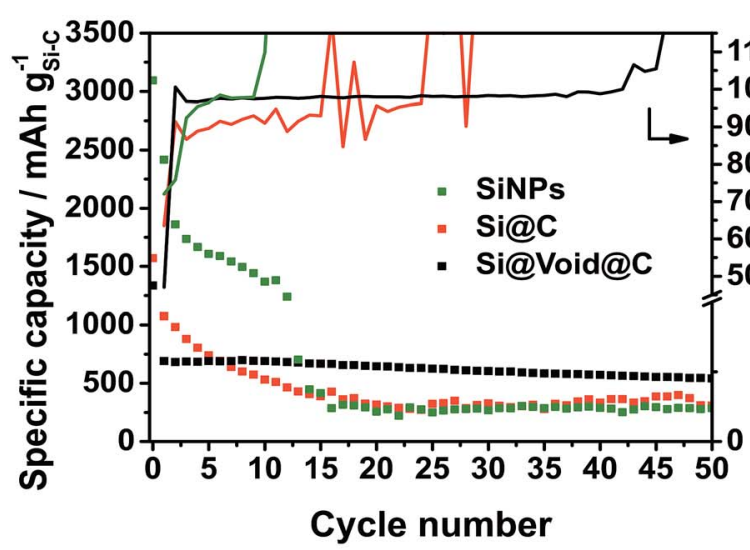

c)

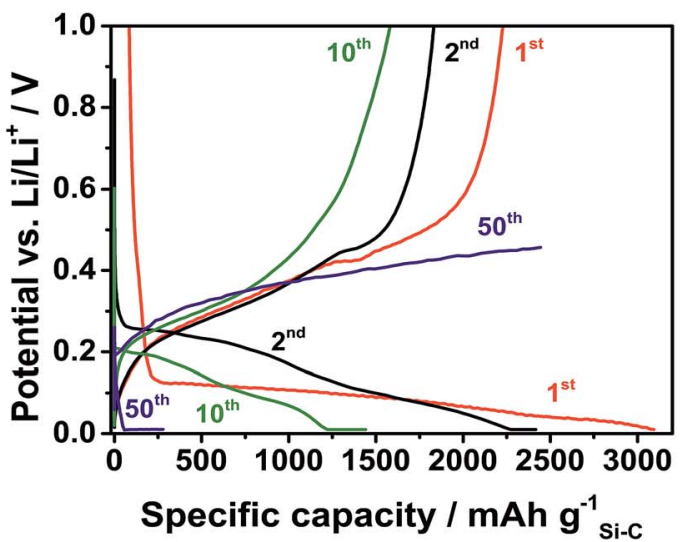

e)

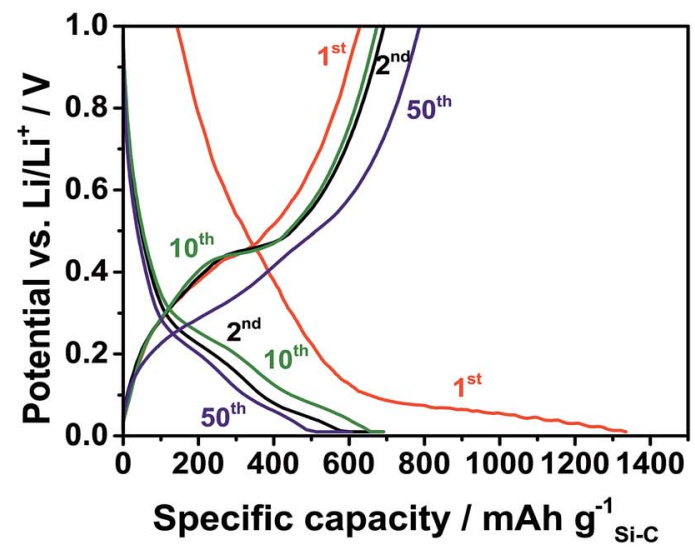

b)

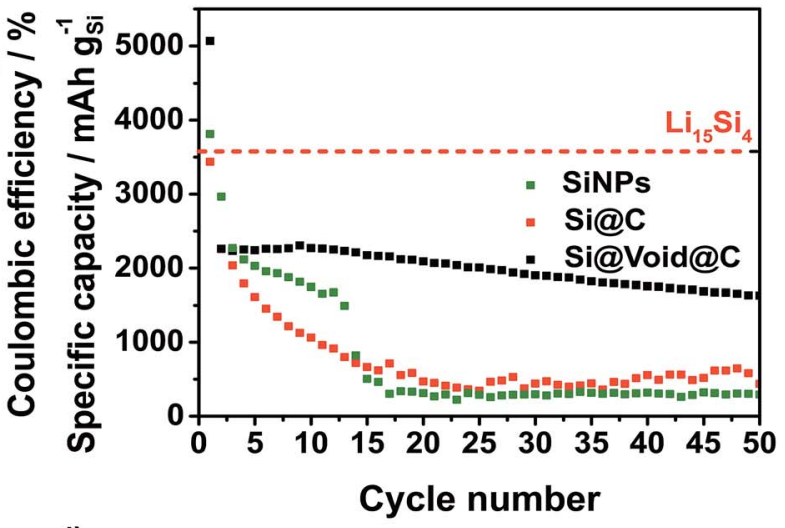

d)


Fig. 6 Results of the half cell testing in coin cells: specific capacity and CE of the SiNP electrode $\left(2.5 \mathrm{mg} \mathrm{cm}^{-2}\right)$, Si@C electrode $\left(3 \mathrm{mg} \mathrm{cm}{ }^{-2}\right)$ and SiavoidaC electrode $\left(2.8 \mathrm{mg} \mathrm{cm}^{-2}\right.$ ) based on the active material (a) and based on the silicon weight (b). Due to SEI formation and silicon loss there is an irreversible capacity and a low CE in the first cycle. The voltage profiles of the SiNP electrode (c), SiaC electrode (d) and Si@void@C electrode (e) imply the lithiation of the crystalline silicon particles and the formation of $\mathrm{Li}_{15} \mathrm{Si}_{4}$. High areal capacities could be achieved using SiavoidaC electrodes (f).

volume change of the silicon rises and the electrode degrades faster. Additionally, with higher loading, lithium diffusion to the active anode material is hampered leading to decreased silicon utilization as well.

Due to the void structure high areal capacities above $2.5 \mathrm{~mA} \mathrm{~h} \mathrm{~cm}^{-2}$ could be achieved with only a slight capacity fading. Another requirement for the transfer to applicable cells is the potentially simple scalability of the Si@void@C composite synthesis. Thus, we were able to increase the batch size from a laboratory scale ( $2 \mathrm{~g}$ batch) to $50 \mathrm{~g}$ with a reproducible electrochemical performance which is shown in Fig. S6b. $\dagger$ From the developed Si-C electrode with at least an area DIN 4A in size, double-sided pouch electrodes $(4.6 \times 7.1$ $\mathrm{cm}^{2}$ ) were cut out using laser-cutting (Fig. 7a). The anode and the cathode were welded on a nickel tap and assembled to a one-layered pouch cell (Fig. 7b).

As can be seen in Fig. $6 f$ the electrochemical performance of the Si@void@C composite with a decreased electrode 
a)

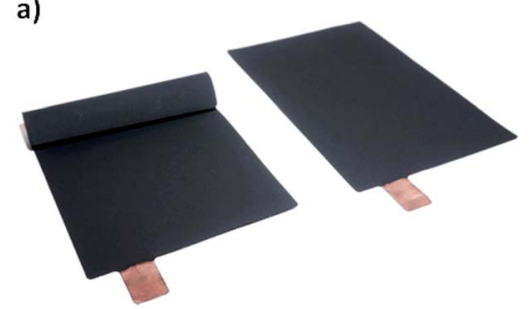

b)

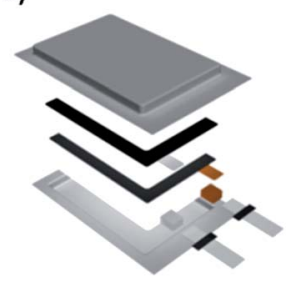

c)

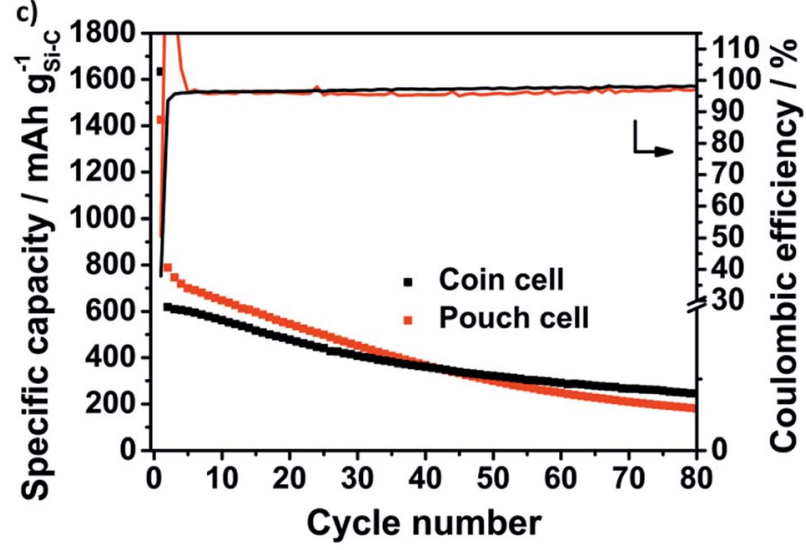

Fig. 7 The double-sided pouch cell electrode (a) and stacked pouch cell (b) could be realized by scaling up the synthesis to $50 \mathrm{~g}$ batches. Specific capacity and CE of the half cell testing in coin and in pouch cells (c): the Siavoid@C electrodes $\left(0.3 \mathrm{mg} \mathrm{cm}^{-2}\right)$ show comparable capacity retention and a stable CE for more than 80 cycles.

loading of $0.3 \mathrm{mg} \mathrm{cm}{ }^{-2} v s . \mathrm{Li} / \mathrm{Li}^{+}$in pouch cells is comparable to the half cell testing in coin cells. In the second cycles $789 \mathrm{~mA} \mathrm{~h} \mathrm{~g}{ }^{-1}$ could be reached in the pouch cell and $619 \mathrm{~mA} \mathrm{~h} \mathrm{~g}^{-1}$ in the coin cell. As explained above, the CE in the first cycle is only $38 \%$ in the coin cell and $50 \%$ in the pouch cell. In the second cycle the $\mathrm{CE}$ of the pouch cell rises above $100 \%$. This could be related to wetting conditions through the irregular pressure distribution in single-layered pouch cells. However, in the following cycles a very stable CE around $97 \%$ in the coin cell and $96 \%$ in the pouch cell could be achieved for more than 80 cycles.

2.2.2 Full cell testing. To replace the unstable, highly reactive lithium anode in $\mathrm{Li}-\mathrm{S}$ cells the $\mathrm{Si}-\mathrm{C}$ electrode has to be previously lithiated in a half cell setup and then the $\mathrm{Li}_{x} \mathrm{Si}-\mathrm{C}$ electrode is assembled $v s$. a sulfur cathode $\left(\mathrm{S}_{8}-\mathrm{C}\right)$. Before full cell testing both electrodes were characterized in half cells $v s$. $\mathrm{Li} / \mathrm{Li}^{+}$to adjust the balancing of the lithiated silicon sulfur cell (SLS) and hence, the respective voltage window is attributed to the fact that the potential slope of the silicon delithiation strongly influences the way of balancing. The ratio of the actual and realistically measured areal capacities of the anode and the cathode has to be correlated to ensure a stable full cell. Thus, the discharge profile of the $\mathrm{S}_{8}-\mathrm{C}$ cathode and the charge profile of the $\mathrm{Li}_{x} \mathrm{Si}-\mathrm{C}$ anode are compared in Fig. $8 \mathrm{a}$ and $\mathrm{b}$ to determine the cut-off voltage for the full cell testing.

Generally, for the full cell concept it is reasonable to overbalance the anode for two reasons: firstly, the compensation of lithium losses through SEI formation and pulverization of the $\mathrm{Li}_{x} \mathrm{Si}-\mathrm{C}$ anode is one issue. Secondly, it is beneficial when the

cathode (lithiation) discharge slope meets the delithiation slope of the anode at a constant potential in order to create a stable difference between the two potentials. The lower the difference between the lithiation slope of the cathode and delithiation slope of the anode, the lower the voltage value where the full cells need to be discharged being detrimental in terms of the electrolyte depletion. According to this the SLS cell on the coin cell level (Fig. 8a) is limited to the anode with a balancing of the practical areal capacities ( $2^{\text {nd }}$ cycle) of the anode : cathode of $5: 3$. Unfortunately, the $\mathrm{Li}_{x} \mathrm{Si}-\mathrm{C}$ pouch anode needs to have a lower loading due to delamination effects during prelithiation at higher loadings. Thus, the SLS pouch cell (Fig. 8b) is limited to the $\mathrm{S}_{8}-\mathrm{C}$ cathode with a balancing anode : cathode of $10: 11$ and the discharge cut-off voltage has to be decreased to $1.11 \mathrm{~V}$ to delithiate the $\mathrm{Li}_{x} \mathrm{Si}-\mathrm{C}$ anode at least. Fig. 8c-f show the specific capacity retention and the corresponding voltage profiles of the SLS cells compared to the Li-S cell. Even though the SLS coin cell has a much lower lithium excess of only $76 \%$ than the $\mathrm{Li}-\mathrm{S}$ cell with a huge lithium excess of about $2000 \%$ the capacity retention obtained for both concepts is comparable. In the beginning ( $2^{\text {nd }}$ cycle) the capacity of the SLS cell is $807 \mathrm{~mA} \mathrm{~h}$ $\mathrm{g}_{\text {sulfur }}{ }^{-1}$ and of the Li-S cell is $830 \mathrm{~mA} \mathrm{~h}_{\text {sulfur }}{ }^{-1}$ and after 50 cycles even $492 \mathrm{~mA} \mathrm{~h} \mathrm{~g}_{\text {sulfur }}{ }^{-1}$ in the SLS cell and $617 \mathrm{~mA} \mathrm{~h}$ $\mathrm{g}_{\text {sulfur }}{ }^{-1}$ in the Li-S cell are reached (Fig. 8c). The CE of the SLS cell is just around $80 \%$ because the used electrolyte is optimized for Li-S cells and is not suited for silicon anodes. ${ }^{\mathbf{8 1 4}}$ Probably, the $\mathrm{LiNO}_{3}$ is consumed in the first cycle and the SEI could not be stabilized.$^{67}$ In this way the electrolyte is decomposed repeatedly and the polysulfide shuttle is promoted.

The voltage profiles in Fig. 8e of the SLS cell show both characteristic plateaus during the discharge process. In comparison to the $\mathrm{Li}-\mathrm{S}$ cell (Fig. S7 $\dagger$ ) the voltage profiles are shifted to lower voltages and the average cell voltage decreases from $2.1 \mathrm{~V}$ in the Li-S cell to around $1.7 \mathrm{~V}$ in the SLS cell because of the higher potential of the lithiation of silicon.

As expected, the SLS pouch cell shows a lower capacity of 348 $\mathrm{mA} \mathrm{h} \mathrm{g}_{\text {sulfur }}{ }^{-1}$ corresponding to a low capacity of $363 \mathrm{~mA} \mathrm{~h}$ $\mathrm{g}_{\text {anode }}{ }^{-1}$ related to the anode in the beginning ( $2^{\text {nd }}$ cycle) and the capacity slowly decreases to $80 \mathrm{~mA} \mathrm{~h} \mathrm{~g}$ sulfur $^{-1}$ (138 mA h $\mathrm{g}_{\text {anode }}{ }^{-1}$ ) after 50 cycles (Fig. 8d). The main reason for this is the overbalanced $\mathrm{S}_{8}-\mathrm{C}$ cathode. Thus, the sulfur could not be utilized completely and lithium is lost steadily because of the anode degradation. The CE is just around $40-50 \%$ and hence, only half of the amount obtained in the coin cell setup, which could be explained by the increased side reactions due to the higher electrolyte amount in the pouch cell and the polysulfide shuttle which could not be suppressed. In line with the low sulfur utilization, the discharge profile (Fig. 8f) exhibits only one plateau at around $1.9 \mathrm{~V}$.

Nevertheless, it was possible to show the feasibility of the SLS cell on the pouch level by elucidating the crucial issues that occur when cell concepts are supposed to be scaled up from the coin cell level which is a important step towards commercialization. It could be underlined that the balancing of the SLS cell needs to be limited to the cathode to compensate lithium losses and to utilize the sulfur cathode completely. The low CE of the SLS cells indicates that research on electrolytes which are suited 
a)

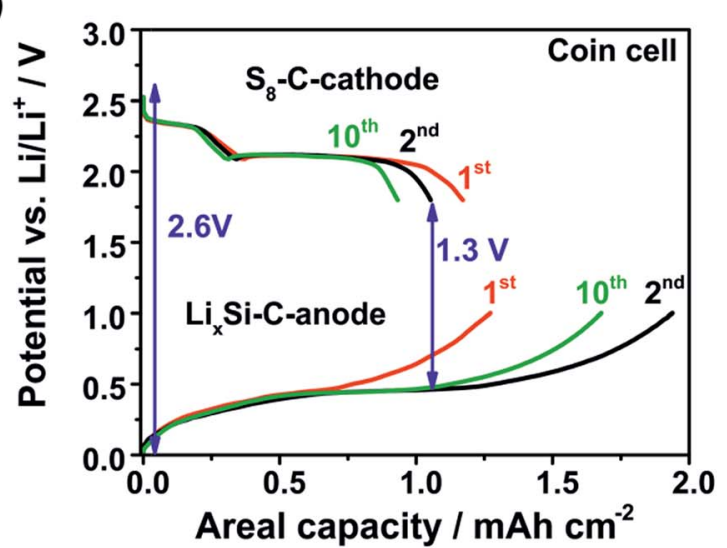

c)

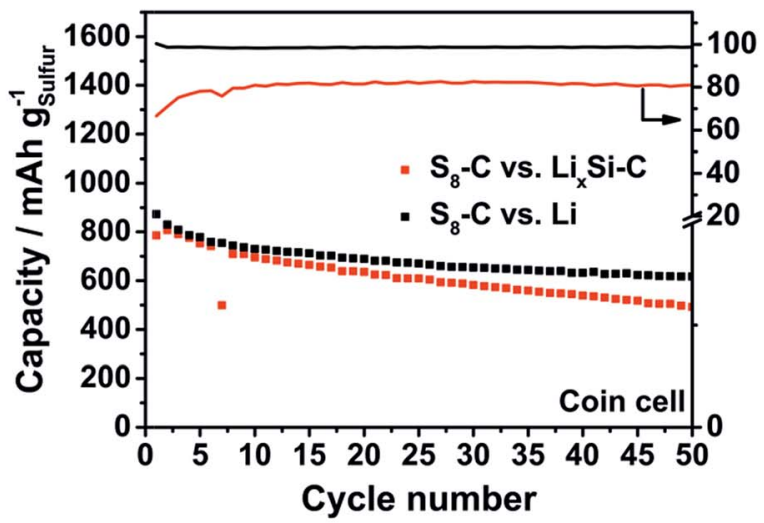

e)

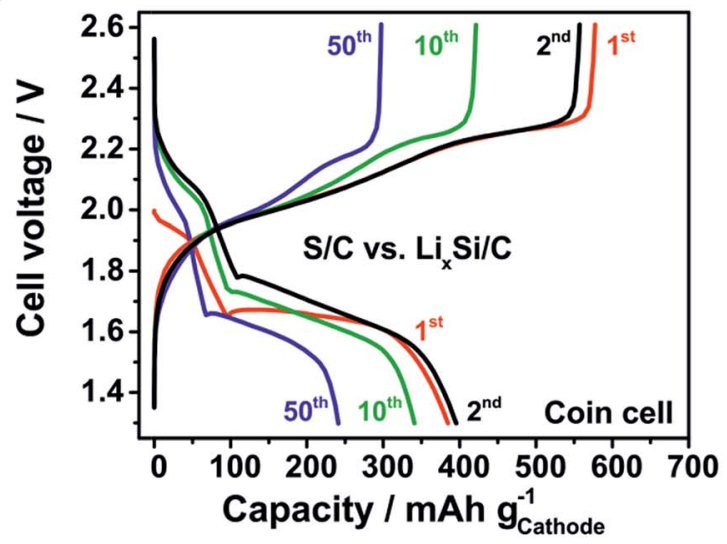

b)

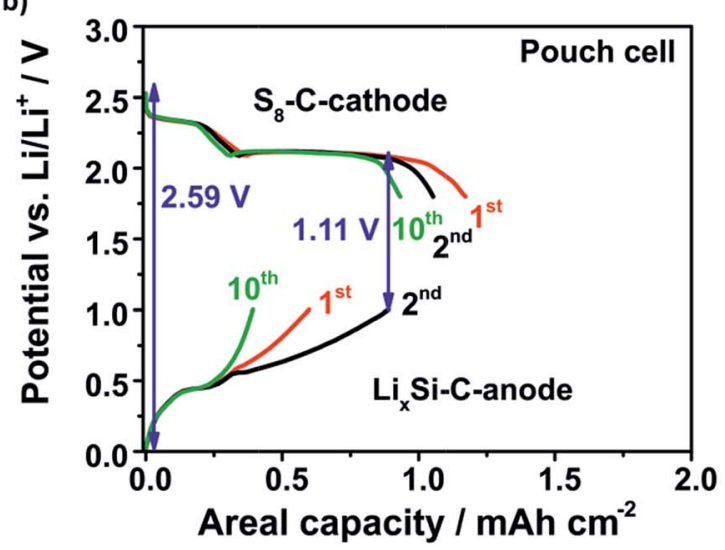

d)



f)

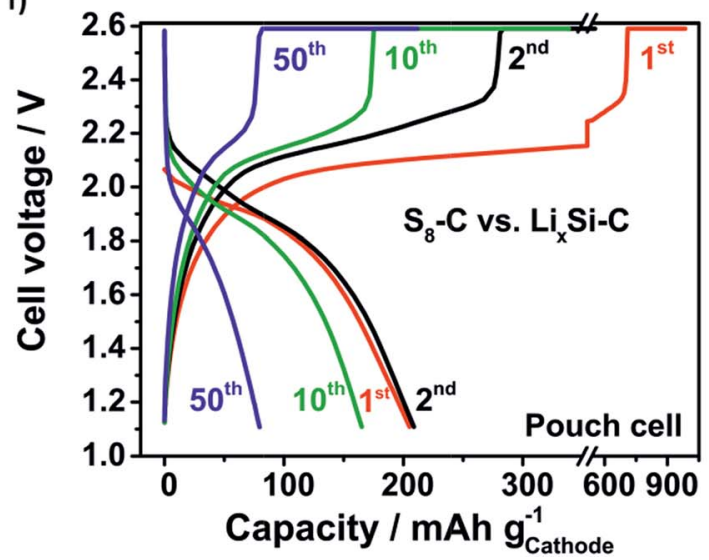

Fig. 8 The balancing of the SLS full cells on the coin cell level (a) which is limited to the anode and on the pouch cell level (b) which is limited to the cathode because of the lower loading of the anode. The results of the full cell testing in coin cells (c and e) and in pouch cells ( $d$ and f): specific capacity ( $c$ and d) and the corresponding voltage profiles (e and f). With much a lower lithium excess of $76 \%$ in the SLS cell, a capacity retention comparable to that of the Li-S cell is achieved.

for SLS cells is crucial to achieve higher capacity retention. ${ }^{\mathbf{1 9}}$ Tailoring of nanostructured silicon composites is necessary but for multilayer pouch cells the realization of electrodes with high active material loadings is challenging.

\section{Experimental}

3.1 Synthesis of the silicon-carbon composite

In order to cover silicon nanoparticles with sulfur, $10 \mathrm{~g}$ SiNPs (Alfa Aesar, 98\%, APS $\geq 50 \mathrm{~nm}$ ) and $34.626 \mathrm{~g}$ sulfur (Sigma
Aldrich, $\geq 99.5 \%$ ) (Si : S $1: 3$ molar ratio) were mixed with a mixer mill (MM400, Retsch) for $5 \mathrm{~min}$ at $25 \mathrm{~Hz}$ and heated for $30 \mathrm{~min}$ at $155{ }^{\circ} \mathrm{C}$. The covered particles (Si@S) were ground with the mixer mill again and $40.220 \mathrm{~g}$ Si@S were suspended in a $178 \mathrm{ml}$ mixture of ethanol/water $(1: 1 \mathrm{v} / \mathrm{v})$. $51.884 \mathrm{~g}$ of sucrose (Sigma Aldrich, $\geq 99 \%$ ) was added and after a $10 \mathrm{~min}$ ultra-sonic treatment, $3459 \mathrm{mg}$ of a $2.5 \mathrm{M}$ sodium hydroxide solution was added dropwise under vigorous stirring. The mixture was heated for $3 \mathrm{~h}$ at $100{ }^{\circ} \mathrm{C}$ 
and $6 \mathrm{~h}$ at $160{ }^{\circ} \mathrm{C}$. To remove the sulfur and carbonize the polymerized sucrose the grinded Si@S@sucrose compound is heated under argon with $10 \mathrm{~K} \mathrm{~min}^{-1}$ to $850{ }^{\circ} \mathrm{C}$ annealed for $2 \mathrm{~h}$.

\subsection{Structural characterization}

The nanoscale structure and morphology of the $\mathrm{Si}-\mathrm{C}$ composite were examined using a TEM JEM-2100 from JEOL $(200 \mathrm{kV}$ acceleration voltage) and SEM DSM 982 GEMINI from Zeiss (7 $\mathrm{kV}$ acceleration voltage) and SU8020 from Hitachi (5 kV acceleration voltage). PXRD experiments were performed with a Pro Panalytical X'pert diffractometer using $\mathrm{Cu} \mathrm{K} \alpha 1$ radiation and a scan range $2 \Theta=10-80^{\circ}$. Raman spectroscopy data were collected using a Renishaw inVia Raman spectrometer under ambient conditions using a laser with a wavelength of $514 \mathrm{~nm}$. By determining the degree of graphitization $I_{\mathrm{D}} / I_{\mathrm{G}}$, the intensities of the $\mathrm{D}$ band and the $\mathrm{G}$ band were calculated by fitting the spectra with a Lorentzian function. A thermal analysis of the pyrolysis was performed using a Netzsch STA 409 PC Luxx simultaneous thermal analyzer combined with an Aëolos QMS 403C quadrupole mass spectrometer. Analogous to the synthesis procedure, the Si@S@sucrose compound was heated at $10 \mathrm{~K} \mathrm{~min}^{-1}$ to $850{ }^{\circ} \mathrm{C}$ for $2 \mathrm{~h}$ under argon flow. To quantify the silicon content, the $\mathrm{Si}-\mathrm{C}$ composite was heated under argon at $10 \mathrm{~K} \mathrm{~min}^{-1}$ to $500{ }^{\circ} \mathrm{C}$ and held for $30 \mathrm{~min}$ and heated again at 5 $\mathrm{K} \mathrm{min}^{-1}$ to $1000{ }^{\circ} \mathrm{C}$ and held for $30 \mathrm{~min}$ using a Netzsch STA 409 PC/PG simultaneous thermal analyzer. The carbon, hydrogen, nitrogen and sulfur contents of the Si@void@C composite were determined using an elemental CHNS analyzer vario MICRO form ELEMENTAR.

\subsection{Electrochemical characterization}

3.3.1 Silicon-carbon composite anode preparation. A slurry containing 80 wt\% active material (Si@void@C, Si@C or SiNPs), 10 wt\% multiwalled carbon nanotubes (MWCNT, Nanocyl 7000, 90\%) and $10 \mathrm{wt} \%$ styrene-butadiene rubber (SBR, Targray, 15\%) was prepared in water using a mixer mill (MM400, Retsch) at $25 \mathrm{~Hz}$ for $15 \mathrm{~min}$. The slurry was directly coated on copper foil (Schlenk, $15 \mu \mathrm{m}$ ) with an automatic film applicator (BYK) and the coatings were dried at $80^{\circ} \mathrm{C}$ for $2 \mathrm{~h}$ and under atmosphere for $24 \mathrm{~h}$. For coin cells $12 \mathrm{~mm}$ electrodes were cut with a heavy duty disc cutter. The electrode thickness ranges from 50 to $60 \mu \mathrm{m}$ and the loading is around $2.8 \mathrm{mg} \mathrm{cm}^{-2}$, which results in a density between 0.45 and $0.55 \mathrm{~g} \mathrm{~cm}^{-3}$. The pouch electrodes $\left(4.6 \times 7.1 \mathrm{~cm}^{2}\right)$ were cut with a custom-made laser cutting system. Their loading is around $0.6 \mathrm{mg} \mathrm{cm}^{-2}$ and they are $30 \mu \mathrm{m}$ thick, which results in a density around $0.2 \mathrm{~g} \mathrm{~cm}^{-3}$. All Si electrodes were dried in a vacuum oven at $80{ }^{\circ} \mathrm{C}$ overnight before cell assembly.

3.3.2 Cathode preparation. The cathode is a mixture of sulfur, carbon and binder, single-side coated on aluminum foil serving as the current collector. The sulfur loading has

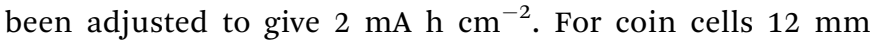
electrodes were cut with a heavy duty disc cutter and the pouch cell cathodes $\left(4.6 \times 7.1 \mathrm{~cm}^{2}\right)$ were cut using a laser.
Before cell assembly the cathodes were dried under vacuum at $50{ }^{\circ} \mathrm{C}$ for $1 \mathrm{~h}$.

3.3.3 Half cell testing. The $\mathrm{Si}-\mathrm{C}$ anodes and the $\mathrm{S}_{8}-\mathrm{C}$ cathodes were tested vs. a lithium anode (MTI Corp., 99\%, diameter $16.5 \mathrm{~mm}$, thickness $250 \mu \mathrm{m}$ ) in CR2016 coin cells (MTI Corp.) which were assembled in a glove box (MBraun) under argon and less than 0.1 ppm $\mathrm{O}_{2}$ and $\mathrm{H}_{2} \mathrm{O}$. The coin cells were filled with $30 \mu$ lelectrolyte containing $1 \mathrm{M}$ bis(trifluoromethane)sulfonamide lithium salt (LiTFSI, Sigma Aldrich, 99.95\%) and 0.25 $\mathrm{M} \mathrm{LiNO}_{3}$ (Sigma Aldrich, 99.98\%, anhydrous) in $1: 1$ (v/v) 1,2-dimethoxyethane (DME, Sigma Aldrich, 99.5\% anhydrous) and 1,3-dioxolane (DOL, Sigma Aldrich, $99.8 \%$, anhydrous). Additionally, a $25 \mu \mathrm{m}$ thick porous polypropylene separator (Celgard 2500) and a stainless steel spacer $(100 \mu \mathrm{m})$ were used. Single-layer pouch cells containing a $\mathrm{Si}-\mathrm{C}$ cathode $\left(4.6 \times 7.1 \mathrm{~cm}^{2}, 0.6 \mathrm{mg} \mathrm{cm}^{-2}\right)$ and a lithium anode $(4.6$ $\left.\times 7.1 \mathrm{~cm}^{2}, 250 \mu \mathrm{m}\right)$, a Celgard 2500 separator $\left(5.0 \times 7.5 \mathrm{~cm}^{2}\right)$ and $2 \mathrm{ml}$ electrolyte (1 M LiTFSI, $0.25 \mathrm{M} \mathrm{LiNO}_{3}$ in $1: 1(\mathrm{v} / \mathrm{v})$ DME/DOL) were stacked in a glove box, as well. The galvanostatic cycling was performed with a BaSyTec CTS cell test system between $10 \mathrm{mV}$ and $1 \mathrm{~V}$ and at a current density of 0.1 $\mathrm{mA} \mathrm{cm}{ }^{-2}$ in the first cycle and $0.5 \mathrm{~mA} \mathrm{~cm}^{-2}$ in the following cycles. In terms of the Si@void@C electrode with a loading of $2.8 \mathrm{mg} \mathrm{cm} \mathrm{cm}^{-2}$ the current density corresponds to a specific current of $36 \mathrm{~mA} \mathrm{~g}^{-1}(\mathrm{C} / 24)$ in the first cycle and to $179 \mathrm{~mA} \mathrm{~g}^{-1}$ (C/5) in the following cycles. The C-rate is based on the weight of silicon (3579 $\mathrm{mA} \mathrm{h} \mathrm{g}{ }_{\mathrm{Si}}{ }^{-1}$ ). During discharge a constant voltage step was applied. The $\mathrm{Li}-\mathrm{S}$ cells were cycled between $1.8 \mathrm{~V}$ and $2.6 \mathrm{~V}$ with a C-rate of $\mathrm{C} / 10$. The capacities of the $\mathrm{Li}-\mathrm{S}$ cells were calculated based on the weight of sulfur (1672 $\left.\mathrm{mA} \mathrm{h} \mathrm{g}^{-1}\right)$.

3.3.4 Full cell testing. For the SLS cells the Si-C anodes are previously lithiated in the half cell set-up as described above. The coin cell Si-C anodes were lithiated 3 times between $10 \mathrm{mV}$ and $1 \mathrm{~V}$ with a current density of $0.1 \mathrm{~mA} \mathrm{~cm}^{-2}$ in the first cycle and 0.5 $\mathrm{mA} \mathrm{cm}{ }^{-2}$ in the second and the third cycle. A constant voltage step is applied in the second and the third discharge step. The pouch $\mathrm{Si}-\mathrm{C}$ anode is lithiated just once with $0.1 \mathrm{~mA} \mathrm{~cm}{ }^{-2}$ until $10 \mathrm{mV}$. After prelithiation the half cells were disassembled and the $\mathrm{Li}_{x} \mathrm{Si}-\mathrm{C}$ anode is cycled versus the described $\mathrm{S}_{8}-\mathrm{C}$ cathode. The SLS coin cells contain a $\mathrm{S}_{8}-\mathrm{C}$ cathode, a Celgard 2500 separator, a $\mathrm{Li}_{x} \mathrm{Si}-\mathrm{C}$ anode, a stainless steel spacer $(1000 \mu \mathrm{m})$ and $12 \mu \mathrm{l}$ $\mathrm{mg}_{\text {sulfur }}{ }^{-1}$ electrolyte (1 M LiTFSI, $0.25 \mathrm{M} \mathrm{LiNO}_{3}$ in $1: 1(\mathrm{v} / \mathrm{v})$ DME/DOL). Accordingly, the single-layer SLS pouch cells consisting of a $\mathrm{S}_{8}-\mathrm{C}$ cathode, a Celgard 2500 separator and $\mathrm{Li}_{x} \mathrm{Si}-\mathrm{C}$ anode and $2 \mathrm{ml}$ electrolyte (1 M LiTFSI, $0.25 \mathrm{M} \mathrm{LiNO}_{3}$ in $1: 1(\mathrm{v} / \mathrm{v})$ DME/DOL) were assembled. The galvanostatic cycling was performed with a BaSyTec CTS cell test system with a C-rate of C/10. The coin cell testing was performed between 1.3 and $2.6 \mathrm{~V}$ and the pouch cells were cycled in a smaller voltage range between 1.11 and 2.59 V. During charging a constant voltage step is applied to the SLS pouch cells.

\section{Conclusions}

In summary, we have synthesized nanostructured siliconcarbon composites via a simple, easily scalable route without 
hydrofluoric acid treatment. Sulfur was used as a low-cost intermediate template to create tailored voids between silicon cores and carbon shells via in situ removal in parallel to the carbon pyrolysis. Due to the void structure, the electrode degradation caused by the volume change of the silicon could be balanced. After 10 cycles, capacities as high as $2270 \mathrm{~mA} \mathrm{~h}$ $\mathrm{g}_{\mathrm{Si}}{ }^{-1}$ (690 $\mathrm{mA} \mathrm{h} \mathrm{g}^{-1}$ ) were achieved and the cycle life could be enhanced compared to pure SiNPs and a Si@C electrode without voids. Due to the high areal capacity of $2 \mathrm{~mA} \mathrm{~h} \mathrm{~cm}^{2}$ the prelithiated $\mathrm{Si}-\mathrm{C}$ anode was successfully combined with a sulfur cathode in a SLS full cell on coin cell and on pouch cell levels. Even with only a small lithium excess of $76 \%$ and a relatively low amount of electrolyte $\left(12 \mu \mathrm{mg}_{\text {sulfur }}{ }^{-1}\right)$ a high capacity of about $807 \mathrm{~mA} \mathrm{~h} \mathrm{~g}_{\text {sulfur }}{ }^{-1}$ ( $2^{\text {nd }}$ cycle) could be achieved, a capacity comparable to that of standard $\mathrm{Li}-\mathrm{S}$ cells which use a much higher lithium excess of up to $2000 \%$.

\section{Conflicts of interest}

There are no conflicts to declare.

\section{Acknowledgements}

This research received funding from the European Union's Horizon 2020 research and innovation programme through the project ALISE (GA no. 666157).

\section{Notes and references}

1 P. Strubel, S. Thieme, T. Biemelt, A. Helmer, M. Oschatz, J. Brückner, H. Althues and S. Kaskel, Adv. Funct. Mater., 2015, 25(2), 287.

2 J. Brückner, S. Thieme, H. T. Grossmann, S. Dörfler, H. Althues and S. Kaskel, J. Power Sources, 2014, 268, 82.

3 M. Agostini, J. Hassoun, J. Liu, M. Jeong, H. Nara, T. Momma, T. Osaka, Y.-K. Sun and B. Scrosati, ACS Appl. Mater. Interfaces, 2014, 6(14), 10924.

4 R. Cao, W. Xu, D. Lv, J. Xiao and J.-G. Zhang, Adv. Energy Mater., 2015, 5(16), 1402273.

5 J. Brückner, S. Thieme, F. Böttger-Hiller, I. Bauer, H. T. Grossmann, P. Strubel, H. Althues, S. Spange and S. Kaskel, Adv. Funct. Mater., 2014, 24(9), 1284.

6 X. Pu, G. Yang and C. Yu, Nano Energy, 2014, 9, 318.

7 J. K. Lee, C. Oh, N. Kim, J.-Y. Hwang and Y.-K. Sun, J. Mater. Chem. A, 2016.

8 M. Piwko, T. Kuntze, S. Winkler, S. Straach, P. Härtel, H. Althues and S. Kaskel, J. Power Sources, 2017, 351, 183.

9 H. Wu and Y. Cui, Nano Today, 2012, 7(5), 414.

10 M. Ling, H. Zhao, X. Xiaoc, F. Shi, M. Wu, J. Qiu, S. Li, X. Song, G. Liu and S. Zhang, J. Mater. Chem. A, 2015, 3(5), 2036.

11 X. H. Liu, L. Zhong, S. Huang, S. X. Mao, T. Zhu and J. Y. Huang, ACS Nano, 2012, 6(2), 1522.

12 H. Kim, M. Seo, M.-H. Park and J. Cho, Angew. Chem., Int. Ed., 2010, 49(12), 2146.

13 J. Xu, Q. Zhang and Y.-T. Cheng, J. Electrochem. Soc., 2015, 163(3), A401-A405.
14 M. Weinberger and M. Wohlfahrt-Mehrens, Electrochim. Acta, 2016, 191, 124.

15 T. Takahashi, M. Yamagata and M. Ishikawa, Prog. Nat. Sci.: Mater. Int., 2015, 25(6), 612.

16 H. Jha, I. Buchberger, X. Cui, S. Meini and H. A. Gasteiger, J. Electrochem. Soc., 2015, 162(9), A1829-A1835.

17 R. Elazari, G. Salitra, G. Gershinsky, A. Garsuch, A. Panchenko and D. Aurbach, Electrochem. Commun., 2012, 14(1), 21.

18 D. A. Dalla Corte, A. C. Gouget-Laemmel, K. Lahlil, G. Caillon, C. Jordy, J.-N. Chazalviel, T. Gacoin, M. Rosso and F. Ozanam, Electrochim. Acta, 2016, 201, 70.

19 M. Piwko, S. Thieme, C. Weller, H. Althues and S. Kaskel, J. Power Sources, 2017, 362, 349.

20 J. Ha and U. Paik, J. Power Sources, 2013, 244, 463.

21 Y. Zhao, L. Peng, Y. Ding and G. Yu, Chem. Commun., 2014, 50(85), 12959.

22 B. Hertzberg, A. Alexeev and G. Yushin, J. Am. Chem. Soc., 2010, 132(25), 8548.

23 C. K. Chan, R. Ruffo, S. S. Hong, R. A. Huggins and Y. Cui, J. Power Sources, 2009, 189(1), 34.

24 V. Chakrapani, F. Rusli, M. A. Filler and P. A. Kohl, J. Power Sources, 2012, 205, 433.

25 A. Krause, S. Dorfler, M. Piwko, F. M. Wisser, T. Jaumann, E. Ahrens, L. Giebeler, H. Althues, S. Schadlich, J. Grothe, A. Jeffery, M. Grube, J. Bruckner, J. Martin, J. Eckert, S. Kaskel, T. Mikolajick and W. M. Weber, Sci. Rep., 2016, 6, 27982.

26 Y. Yang, M. T. McDowell, A. Jackson, J. J. Cha, S. S. Hong and Y. Cui, Nano Lett., 2010, 10(4), 1486.

27 M. Hagen, E. Quiroga-González, S. Dörfler, G. Fahrer, J. Tübke, M. J. Hoffmann, H. Althues, R. Speck, M. Krampfert, S. Kaskel and H. Föll, J. Power Sources, 2014, 248, 1058.

28 Y.-Y. Kim, J.-H. Lee and H.-J. Kim, Phys. E, 2017, 85, 223.

29 G. Hwang, H. Park, T. Bok, S. Choi, S. Lee, I. Hwang, N.-S. Choi, K. Seo and S. Park, Chem. Commun., 2015, 51(21), 4429.

30 Y.-X. Yin, S. Xin, L.-J. Wan, C.-J. Li and Y.-G. Guo, J. Phys. Chem. C, 2011, 115(29), 14148.

31 S.-K. Lee, S.-M. Oh, E. Park, B. Scrosati, J. Hassoun, M.-S. Park, Y.-J. Kim, H. Kim, I. Belharouak and Y.-K. Sun, Nano Lett., 2015, 15(5), 2863.

32 C. Shen, M. Ge, A. Zhang, X. Fang, Y. Liu, J. Rong and C. Zhou, Nano Energy, 2016, 19, 68.

33 L. Liu, J. Lyu, T. Li and T. Zhao, Nanoscale, 2016, 8(2), 701. 34 Y. Yan, Y.-X. Yin, S. Xin, J. Su, Y.-G. Guo and L.-J. Wan, Electrochim. Acta, 2013, 91, 58.

35 J. Sourice, A. Bordes, A. Boulineau, J. P. Alper, S. Franger, A. Quinsac, A. Habert, Y. Leconte, E. de Vito, W. Porcher, C. Reynaud, N. Herlin-Boime and C. Haon, J. Power Sources, 2016, 328, 527.

36 L. Zhang, Y. Wang, G. Kan, Z. Zhang, C. Wang, Z. Zhong and F. Su, RSC Adv., 2014, 4(81), 43114.

37 R. C. de Guzman, J. Yang, M. M.-C. Cheng, S. O. Salley and K. Y. Simon Ng, J. Power Sources, 2014, 246, 335. 
38 J. Hassoun, J. Kim, D.-J. Lee, H.-G. Jung, S.-M. Lee, Y.-K. Sun and B. Scrosati, J. Power Sources, 2012, 202, 308.

39 H. S. Kim, T.-G. Jeong and Y.-T. Kim, J. Electrochem. Sci. Technol., 2016, 7(3), 228.

40 B. Li, S. Li, J. Xu and S. Yang, Energy Environ. Sci., 2016, 9(6), 2025.

41 D. Zhou, M. Liu, Q. Yun, X. Wang, Y.-B. He, B. Li, Q.-H. Yang, Q. Cai and F. Kang, Small, 2017, 13(3), 1602015.

42 Z. Lu, N. Liu, H.-W. Lee, J. Zhao, W. Li, Y. Li and Y. Cui, ACS Nano, 2015, 9(3), 2540.

43 N. Liu, H. Wu, M. T. McDowell, Y. Yao, C. Wang and Y. Cui, Nano Lett., 2012, $12(6), 3315$.

$44 \mathrm{H}$. Wu, G. Zheng, N. Liu, T. J. Carney, Y. Yang and Y. Cui, Nano Lett., 2012, 12(2), 904.

45 S. Chen, M. L. Gordin, R. Yi, G. Howlett, H. Sohn and D. Wang, Phys. Chem. Chem. Phys., 2012, 14(37), 12741.

46 S. Iwamura, H. Nishihara and T. Kyotani, J. Phys. Chem. C, 2012, 116(10), 6004.

47 X. Li, P. Meduri, X. Chen, W. Qi, M. H. Engelhard, W. Xu, F. Ding, J. Xiao, W. Wang, C. Wang, J.-G. Zhang and J. Liu, J. Mater. Chem., 2012, 22(22), 11014.

48 X.-y. Zhou, J.-j. Tang, J. Yang, J. Xie and L.-l. Ma, Electrochim. Acta, 2012, 87, 663.

49 L. Pan, H. Wang, D. Gao, S. Chen, L. Tan and L. Li, Chem. Commun., 2014, 50(44), 5878.

50 Y. Ru, D. G. Evans, H. Zhu and W. Yang, $R S C A d v ., 2014,4(1)$, 71.

51 H. Tao, L.-Z. Fan, W.-L. Song, M. Wu, X. He and X. Qu, Nanoscale, 2014, 6(6), 3138.

52 C. Pang, H. Song, N. Li and C. Wang, RSC Adv., 2015, 5(9), 6782.
53 X. Xiao, W. Zhou, Y. Kim, I. Ryu, M. Gu, C. Wang, G. Liu, Z. Liu and H. Gao, Adv. Funct. Mater., 2015, 25(9), 1426.

54 L. Y. Yang, H. Z. Li, J. Liu, Z. Q. Sun, S. S. Tang and M. Lei, Sci. Rep., 2015, 5, 10908.

55 T. Jaumann, M. Herklotz, M. Klose, K. Pinkert, S. Oswald, J. Eckert and L. Giebeler, Chem. Mater., 2015, 27(1), 37.

56 L. Su, J. Xie, Y. Xu, L. Wang, Y. Wang and M. Ren, Phys. Chem. Chem. Phys., 2015, $17(27), 17562$.

57 K. McCormac, I. Byrd, R. Brannen, B. Seymour, J. Li and J. Wu, Phys. Status Solidi, 2015, $212(4), 877$.

58 N. Liu, Z. Lu, J. Zhao, M. T. McDowell, H.-W. Lee, W. Zhao and Y. Cui, Nat. Nanotechnol., 2014, 9(3), 187.

59 A. Perriot, D. Vandembroucq, E. Barthel, V. Martinez, L. Grosvalet, C. Martinet and B. Champagnon, J. Am. Ceram. Soc., 2006, 89(2), 596.

60 J. Lin, J. He, Y. Chen, Q. Li, B. Yu, C. Xu and W. Zhang, Electrochim. Acta, 2016, 215, 667.

61 Y. Zhou, S. L. Candelaria, Q. Liu, E. Uchaker and G. Cao, Nano Energy, 2015, 12, 567.

62 M. Ko, S. Chae and J. Cho, ChemElectroChem, 2015, 2(11), 1645.

63 A. Tokranov, R. Kumar, C. Li, S. Minne, X. Xiao and B. W. Sheldon, Adv. Energy Mater., 2016, 6(8), 1502302.

64 M. Ashuri, Q. He and L. L. Shaw, Nanoscale, 2016, 8(1), 74.

65 M. N. Obrovac and V. L. Chevrier, Chem. Rev., 2014, 114(23), 11444.

66 Z. Sun, S. Tao, X. Song, P. Zhang and L. Gao, J. Electrochem. Soc., 2015, 162(8), A1530-A1536.

67 T. Yim, M.-S. Park, J.-S. Yu, K. J. Kim, K. Y. Im, J.-H. Kim, G. Jeong, Y. N. Jo, S.-G. Woo, K. S. Kang, I. Lee and Y.-J. Kim, Electrochim. Acta, 2013, 107, 454. 